\title{
Poverty, livelihoods and the conservation of nature in biodiversity hotspots around the world
}

\author{
Jetske Bouma ${ }^{1}, \mathrm{KJ}$ Joy $^{2}$, Vu Cong Lan, ${ }^{3}$ Alexander Lopez Ramirez ${ }^{4}$ and Maronel Steyn ${ }^{5}$
}

\section{Preliminary version, please do not quote}

\section{Abstract:}

The high incidence of poverty in biodiversity hotspots around the world has given rise to a debate about the potential of integrated development-conservation approaches to help alleviate poverty and protect biodiversity at the same time. Specifically, involving local communities in the management of protected areas is expected to improve biodiversity protection and reduce poverty and possible adverse livelihood effects, assuming that there are poverty-nature linkages and that local communities are willing to cooperate in rule enforcement and control. Using data from four biodiversity hotspots around the world (South Africa, Costa Rica, Vietnam and India) the analysis in this paper indicates that livelihoods in biodiversity hotspots do not necessarily depend on nature and that for households to contribute to rule enforcement some conditions have to be met. In order to effectively improve biodiversity protection and alleviate poverty specific attention needs to be paid to local community characteristics, household livelihood strategies, the organization of protected area management and the wider context in which decision-making takes place.

Key-words: poverty-nature linkages, protected area management, co-management, conservation-development trade-offs.

1 Institute for Environmental Studies (IVM), VU University, Amsterdam, The Netherlands. E-mail: Jetske.bouma@ivm.vu.nl

$\frac{2}{2}$ Society for Promoting Participative Ecosystem Management (SOPPECOM), Pune, India. E-mail: joykjjoy@gmail.com

${ }^{3}$ National Institute of Agricultural Planning and Projection (NIAPP), Hanoi, Viet Nam. E-mail: htatniapp@hn.vnn.vn

${ }^{4}$ Universidad Nacional de Costa Rica (UNA), Heredia, Costa Rica. E-mail: alope@una.ac.cr

${ }^{5}$ Council for Scientific and Industrial Research (CSIR),Natural Resources and Environment (NRE), Stellenbosch, South Africa. E-mail: MSteyn@csir.co.za 


\section{Introduction}

Globally, biodiversity is being depleted at an alarming rate (UN 2010). This is a problem, not only because biodiversity is intrinsically valuable, but also because it provides the basis for many ecosystem services that are crucial for human well-being. The most effective way of conserving biodiversity is through the establishment of protected areas (Bruner et al. 2001). Initially, protected areas were established by simply putting a fence around biodiversity-rich ecosystems, but given the often negative impacts on local livelihoods (Cernea and Schmidt-Soltau 2006), alternative, more inclusive mechanisms to protect biodiversity are increasingly sought. Recent findings suggest that protected area establishment might also affect local livelihoods positively, by generating income through eco-tourism (Andam et al 2010, Sims 2010). ${ }^{1}$

Influential reports like MA (2005) and TEEB (2009) are suggesting that biodiversity protection benefits local livelihoods by improving the quality of the ecosystem on which local communities depend. Since it is the poor who are expected to depend most on ecosystem services for their livelihoods, it is even argued that biodiversity conservation has important poverty alleviation effects (UN 2010). The literature on integrated conservation-development approaches suggests, however, that the linkages between nature conservation, income generation and poverty alleviation are not so simple, and that there might be important conservation-development trade-offs (Barrett et al. 2005, Stefan-Dewenter et al 2007). For example, one reason why poverty and biodiversity are spatially correlated (Fisher and Cristoph 2007) is that biodiversity-rich regions are usually remote and economically under-developed, which also explains why people are poor (Dasgupta et al. 2004). Another reason is that local communities might not directly depend on the ecosystem for their livelihood (Salafsky and Wollenberg 2000), so that improving the quality of the ecosystem does not alleviate their poverty or have other significant livelihood effects.

The aim of this paper is to assess the linkages that exist between poverty, livelihoods and nature in four biodiversity hotspots around the globe in order to analyze how biodiversity might be protected while avoiding potential negative livelihood effects. The analysis is based on primary data from 670 households spread over 22 villages in Costa Rica, South Africa, Vietnam, and India. Villages were selected on the basis of their location near (or inside) protected areas and households were selected randomly to allow for a representative analysis of poverty, livelihood and nature linkages in the study sites.

\footnotetext{
${ }^{1}$ Wittmeyer et al (2008) indicate that the tourism development generated by protected area establishment is negatively affecting the primary goal of protected area establishment, nature conservation. This actually suggests that even when conservation benefits local livelihoods, there might still be conservationdevelopment trade-offs.
} 
Linkages between poverty, livelihoods and nature are grounded in the strategies people use to make a living, ie the livelihood strategies used for generating income and meeting subsistence needs. Sunderlin et al (2005) give an overview of the types of livelihood strategies encountered in forest ecosystems, strategies ranging from traditional hunter-gathers to in-migrant laborers working in plantations and mines. Clearly, hunter-gathers depend directly on the ecosystem for their livelihood, whereas in-migrants have a very different relation with the ecosystem and mostly depend on the ecosystem for non-productive uses (water, fuel). Salafsky and Wollenberg (2000) argue that the strength of the nature-livelihood linkage determines the likelihood of potential trade-offs between conservation and development: the stronger the link, ie the more direct livelihoods depend for their survival on nature, the more likely that conservationdevelopment trade-offs can be avoided and that synergies between conservation and local development can be found.

Considering the specific type of linkages between biodiversity and livelihoods it is important to acknowledge the direct contribution that biodiversity makes to local livelihoods and its indirect role. Biodiversity plays a direct role in people's livelihoods by providing medicine, craft and building material and food (MA 2005). Also, it can benefit local livelihoods directly through its recreational value, for example through the generation of eco-tourism returns. Clearly, biodiversity might also have cultural and spiritual value, but in this paper these values will not be addressed. Indirectly, biodiversity contributes to local livelihoods through the provision of ecosystem services. The concept of ecosystem services became popular after the Millennium Ecosystem Assessment (2005), which introduced the term to underline the inextricably linkages between biodiversity, ecosystems and human well-being. Ecosystem services are 'the benefits people obtain from ecosystems' and by putting ecosystem services central in the debate on nature conservation, the Millennium Ecosystem Assessment stresses the societal benefits of nature conservation and the need to align conservation and development goals. Important ecosystem services are food, fuel, timber and water provision, carbon storage and sequestration, soil formation, climate and disease regulation, aesthetic benefits and spiritual values (MA 2005). The ecosystem services that we will consider in this paper are the provisioning services of food, timber, water, fodder, medicine and non-timber forest products (NTFP's). Biodiversity might not always be crucial for provisioning these services (a monoculture production forests also provides timber) but this is an issue we will not further explore here.

Given that poverty is relatively high in most biodiversity hotspots (Fisher and Christoph 2007) it is important to pay specific attention to the poor. Poor people tend to depend more on the ecosystem for their livelihood, given that they usually have few assets and little or no access to agricultural land. Because poor people are especially vulnerable to changes, avoiding adverse impacts from conservation is especially crucial for the poor. 
The literature distinguishes two types of poverty (Anand and Sen 1997, Sen 1995): Absolute poverty, i.e when people cannot meet their basic human needs, and relative poverty, when other people are relatively better-off. Whether people are poor is usually assessed by measuring people's (monetary and non-monetary) income, but indicators like literacy and health status are increasingly used as well. The Worldbank's poverty indicator of a dollar a day (purchasing power) is a good example of an absolute poverty measure, a relative poverty measure being, for example, a society's lowest income quantile. Scholars like Amartya Sen have pointed out that even when people have sufficient means they might not be able to fulfill their needs because they have no voice in decision-making, lack the capacity to pursue their needs (poor health, illiteracy) or are simply not safe (See Sen 1983, 1995). This realization has given rise to a broader interpretation of poverty in which people's ability to participate in decision-making and access to health and educational services play an important role. In this study, we are specifically interested in this broader interpretation of poverty, ie whether people can influence the decision-making processes and developments affecting their livelihoods.

Focusing on people's capacity to influence decision-making shifts attention from the outcomes of decision-making to the means: Clearly, income levels remain important, but by including attention for the inclusiveness of decision-making processes the broader set of mechanisms is included that can help people reduce the vulnerability of their livelihoods and better cope with change. This has partly been the rationale also for developing more inclusive approaches to biodiversity conservation; by including local communities in protected area management their interests are better represented and they can better cope with livelihood change. Usually, protected area establishment implies that local communities are heavily constrained in their use of natural resources, or are even no allowed to enter the protected area at all (Hayes 2006) This often leaves them more vulnerable than before park establishment, since they are limited in their livelihoods or even displaced (Cernea andSchmidt-Soltau 2006). Another reason for including communities in park management is that communities often have local knowledge that can help reduce park monitoring and enforcement costs. This can help improve the effectiveness of biodiversity conservation, through better rule enforcement , monitoring and control (Danielsen et al. 2008)

Thus, involving communities in park management might improve biodiversity conservation and reduce negative livelihood impacts at the same time (Barrett et al. 2005). This requires, however, that communities are also willing to cooperate in park management, Stern (2008) showing that this depends on the trust people have in park management and the perceived legitimacy of the park. In addition, Danielsen et al (2008) indicate that the willingness to cooperate depends on the benefits households can obtain from improved park management, which brings us back to the start of this section, and focus of this paper, i.e the extent to which livelihoods and nature are linked. 
In this paper we will explore the potential for community co-management by assessing the linkages between poverty, nature and local livelihoods and by assessing people's willingness to cooperate in the management of the park. In several of the study sites, communities already play a limited role in park management, whereas in other sites their current involvement in protected area management is nil. We focus on the household characteristics that determine whether households are willing to collaborate in rule enforcement, and assess whether respondents feel able to influence the management of the park. In the next section we introduce the study sites and elaborate our empirical approach.

\section{Study sites, data collection and empirical approach}

Field sites were selected as part of the EU funded FP7 LiveDiverse project ${ }^{2}$ on the basis of the site a) being a biodiversity hotspot, b) including one or more protected areas and c) being a riparian ecosystem. Hence, in South Africa the Mutale basin was selected (including Makuya park and the indigenous protected area of lake Fundudzi), in India the Warana basin (including Chandoli national park) and in Costa Rica the Terraba basin (including the Terraba-Sierpe wetland and the Boruca indigenous reserve). In Vietnam, the study region did not include a riparian ecosystem, but was confined to $\mathrm{Ba}$ Be national park and $\mathrm{Na}$ Hang nature reserve.

The Makuya Park in South Africa was originally laid out in the mid 1980s as part of the Kruger 'national' wildlife park. The park is one of the successful land restitution claims in the Province, where land was given back to the rightful owners, the tribal authorities of Makuya, Mutele and Mphaphuli (Lahiff 1997). The Park covers an area of 18,000 ha and is co-managed by two government departments and the three tribal authorities, although no formal co-management agreement has been signed by the community due to political conflict. Presently, Makuya Park is managed by full-time staff mostly appointed from the three traditional communities who own the land. Apart from the money received from government for rental of the land on an annual basis, the communities also have restricted access to the conservation area (via permission from their traditional authority) to collect firewood, plants for medicinal purposes and to fish. Communities from time-to-time receive meat from animals killed during culling or hunting concessions. Illegal hunting permits and poaching of wildlife is the major cause for concern and threat to conserving biodiversity in the protected area. The sacred Fundudzi lake at the top of the Mutale basin is part of the study site as well.

\footnotetext{
${ }^{2}$ The LiveDiverse project is an EU funded FP7 research project that analyses the linkages between local livelihoods and biodiversity protection, paying specific attention to the cultural-spiritual identity of local communities and how this influences, and is affected by, the protection of biodiversity and natural resource use. More information about the LiveDiverse project can be found on www.livediverse.eu
} 
The Chandoli National Park is situated at the northern part of the Western Ghats in the western part of Maharashtra state, India. It covers an area of 31.900 ha. It was initially declared as a Wild Life Sanctuary in 1985, with an area of 30.900 ha under section 18 of Wildlife (Protection) Act 1972. In 2004 the sanctuary was upgraded to that of a National Park and in 2007it has been declared as part of Sahyadri Tiger Reserve which also comprises the adjoining Koyana and Radhnagari Sanctuaries. The park is rich in biodiversity and includes various endemic animal and plant species. Wild animals like Indian gaur, wild boar, sambar, leopard and tiger have been reported in Chandoli. The forest types include western tropical hill forests, semi evergreen forests, and southern moist mixed deciduous forest. The area is also known for the plant Narkya (Mappia foetida) and it contains the anticancer compound camptothecin (CPT), the only known curative agent for breast cancer. Smuggling has been going on for more than five years and it is exported to Japan where there is a huge demand. Because of the strict action by the forest department in the last couple of years, this illegal extraction and trade have been to some extent controlled. Out of the total 33 villages/hamlets within the park area, 29 villages have been relocated and four villages/hamlets are still inside the park.

$\mathrm{Ba}$ Be national park is situated in North East Vietnam, $254 \mathrm{~km}$ from Ha Noi. The total $\mathrm{Ba}$ Be park is 7,610 ha, including 3226 ha of strictly protected forest, 4084 ha of buffer zone and 300 ha surface water. $\mathrm{Ba} \mathrm{Be}$ has been recognized as the national history cultural heritage in 1986 and ASIAN's Heritage in 2003. There are 524 households $(3,200$ people) living in the strict prevention zone and 6,000 living in the buffer zone. Ethnic minorities are Tay, H'Mong, Dao, Nung and Kinh. Tay people live in wooden houses and are traditionally fishers and weavers, H'mong traditionally depend on hunting and shifting cultivation. The establishment of the park constrained local livelihoods, but also resulted in additional income sources: households are paid for forest protection, local tourism has been developed and agricultural extension services are offered to park inhabitants. The main threats to biodiversity protection in the park are continuing forest clearance for upland agriculture, illegal burning, collection of timber and other plant products, and hunting for meat and the wild animal trade.

$\mathrm{Na}$ Hang nature reserve is located near $\mathrm{Ba} \mathrm{Be}$ national park (the two parks may become connected) and measures 41,930 ha, including a strict protection area of 27,520 ha, 12,910 ha buffer zone and an administrative area of 1,500 ha. Ethnic minority groups include the Tay, Dao, Kinh and H'Mong. The nature reserve was designated as a reversed forest area to protect biodiversity. The construction of the Gam river dam near the park affected the reserve. The main threats to biodiversity come from the people living in and around $\mathrm{Na}$ Hang nature reserve. Many households living in the park still rely on natural resources exploitation to support their livelihood and land shortage is a problem. Shifting cultivation, livestock grazing and over-exploitation of forest products are specifically threatening biodiversity conservation in the park. 


\section{Text box 1: Biodiversity in Ba Be National Park and Na Hang nature reserve, Viet Nam}

According to Hill et al. (1997) the flora in Ba Be national park and Na hang reserve is composed of 603 vascular plant species, ten species of which have been listed in the Vietnam Red Data Book. Vegetation coverage mainly includes two types of forests: the limestone and evergreen forests. Limestone forests are distributed on steep mountainsides, own thick plant cover and take most of the park area. Evergreen forests are distributed on low earthen hills covered with thicker soil layer. Species of low land forests are more diverse than those found on limestone mountains (Hill et al. 1997). Rare mammals include the presence of the Francois' langur (Semnopithecus francoisi) and Ownston's Banded Civet (Hemigulus ownstoni). Francois' langur was found in 1995 along the second bank of the Ba Be Lake and, in 2001 rediscovered nearby Da Dang Guard Post. In the park, the Snub-nosed Monkey avunculus can be found in core zone. The animal was reported as disappeared until it had been rediscovered in Na Hang nature reserve in 1992. Interviews with hunters confirmed the existence of three flocks in the Southward of the park. The Vietnamese Salamander species (Paramesotriton deloustali) was recently discovered in the southern sector of the park Finally, there are 54 species of fish listed for Ba Be Lake, covering $25 \%$ of the freshwater fish fauna of North Vietnam, among them, 10 species listed in Red Data Book of Vietnam.

The Terraba Sierpe National Wetland is a protected area located in the Osa Conservation Area on the Southern Pacific coast of Costa Rica representing the biggest mangrove zone in Costa Rica and on the Pacific line of Central America. Due to its ecological characteristics and the ecosystem services that it provides, it was declared a Ramsar Site in 1951 . The wetland is characterized by a great variety of mangrove forest. Different fish species, migratory birds, and reptiles like boas, crocodiles, caimans and turtles, are the most representative fauna found in the wetland. Despite its importance, the legal and institutional framework in the wetland has not been clear and the laws regulating land use and fishing inside the wetland are not being enforced: there is one guard for controlling 16.700 ha of wetland. Inside the wetland, several fishing communities are located, whose position is rather unclear.

The Boruca indigenous territory located in the more upstream part of the Terraba basin, was among the first indigenous reserves established in Costa Rica in 1956. The lands currently on the reservations were named baldíos (common lands) by the General Law of Common Lands, passed by the national government in 1939, making them the inalienable and exclusive property of the indigenous people. The subsequent law of the Instituto de Tierras y la Colonización de Costa Rica (ITCO or Institute of Lands and Colonization) passed in 1961, transferred the baldíos to state ownership. The Indigenous Law of Costa Rica (La Ley Indígena de Costa Rica) passed in 1977, laid out the fundamental rights of the indigenous peoples. This law defined "indigenous", established that the reserves would be self-governing, and set limitations on land use within the reserves. The population of the Reserva Indígena Boruca subsists mainly on small-scale agriculture and the profits reaped from the sale of indigenous crafts. 
To collect information about the poverty-livelihood-nature linkages in the study sites we developed a household survey. For the survey, respondents were asked about household composition, livelihood strategies and the household's access to land, drinking water, electricity and fuel. Also, livestock ownership, purpose and feed sources were addressed in the survey and crop choice and productivity information was collected as well. Respondents were asked about the products household members collect in nature and about their participation in voluntary organizations at village scale. Household income information was collected by asking respondents to indicate their monthly, average household income from a predefined range of income categories and household vulnerability was assessed by inquiring about food security and the coping strategies used. Finally, information was collected about respondent's perceptions regarding the impact of protected area establishment and management, the respondent's trust in other people and the local authorities and respondent's beliefs. A full version of the household survey is available on the LiveDiverse website (www.livediverse.eu).

For the household survey, a selection of study villages was made within the field sites The criteria for village selection were a) location near or inside a protected area and b) location in the basin. Within these villages a random selection of approximately $10-20 \%$ of the households was made. Due to differing ambitions and aspirations of the LiveDiverse project partners, the total number of completed household surveys differs between the sites: In Costa Rica, 123 surveys were conducted in 4 villages. In South Africa, 116 surveys in 5 villages, In Vietnam 292 surveys in 10 villages and in India 509 surveys in 9 villages. Based on the distance of the study villages to the protected area, for this paper a selection of villages from the total sample was made. Only those villages located less than $15 \mathrm{~km}$ from a protected area were included, meaning that one village was dropped from the South African sample and 5 villages were dropped from the Indian database.

To ensure participation in the survey and to minimize implementation costs, the household survey was developed such that implementation per household would take less than an hour. As a consequence, the information collected in the survey has been highly standardized and time-consuming questions, like for example with regard to health issues, capital assets or the household's production and consumption decisions were left out. The advantage of this approach is that respondents were not burdened with long and detailed questions. The limitation is that in some cases the information collected only gives a rough indication of the underlying poverty-nature linkages and of the issues concerning protected area management and ecosystem use. To facilitate implementation of the survey, a household survey protocol was developed and the training of the surveyors was coordinated by the VU University, the Netherlands. 
For the analysis we combined data from all the study sites but conducted separate analysis for the different countries: the differences between the countries in terms of cultural, economic, institutional and environmental context are such that we felt a combined analysis would not be appropriate. We did, however, estimate the same statistical model for each country to allow for a comparison of the results. Data from different villages were pooled in the analysis, but we control for village characteristics like distance to the protected area and location in-or outside the park. We did not control for park characteristics in the analysis, but we address park characteristics in the text.

The first part of the analysis focuses on the differences in poverty-livelihood-nature linkages between the study sites. With this aim, we compare averages for important poverty, livelihood and ecosystem dependence indicators and discuss the differences between the sites. In addition, we estimate a Probit model using Stata, a statistical software package, to assess the factors determining the probability that respondents consider the collection of natural products important for the households livelihood.

The second part of the analysis focuses on park management and the extent to which respondents feel they can influence decision-making at different scales. First, an assessment is made of the perceived impact of park establishment. Second, we consider respondent perceptions of park management and the extent to which respondents feel they can influence park management or not. Again, we estimate a Probit model, assessing the factors that determine whether respondents feel they can influence the management of the park. In this, we account for respondent and village characteristics, including the respondent's trust in other people, in the authorities, membership of voluntary organizations and being part of the region's majority ethnic and/or religious group. Finally we estimate a Probit model for explaining the probability that a respondent is willing to report people that break the rules. Using the same explanatory variables as in the preceding models, we show that this willingness depends on household and village characteristics and on the perceived influence in the management of the park. In the annex we present an overview of the explanatory variables. Qualitative findings of village meetings and interviews were used to interpret the findings and illustrate some of the results.

Using the same model specifications for each study site resulted in a number of dropped variables in some cases since optimal model specification differed between the sites. For all three models, we tried to find the specification that best fitted the different study sites, but in some cases trade-offs between the model specifications for the different countries arise. In the explanation of the analytical outcomes we will address such trade-offs and explain the impact of different model specifications on the results. 


\section{Results}

1. Livelihood strategies and linkages with nature

The results presented in table 1 indicate that there are significant differences in livelihood strategies between the sites. In Vietnam and India, agriculture is the main livelihood strategy, whereas in the Costa Rica and South Africa agriculture plays a relatively minor role. In Costa Rica, this is because large scale commercial agriculture is dominant in the region, and most households own little or no land. In South Africa, apartheid fundamentally changed livelihoods from agriculture-dependant to migration labor-dependant and since access to land is still limited, most households mostly depend on migratory labor and government pensions and grants (NB this also explains why figures don't add up to 100\%). Surprisingly, the \% of households receiving remittances in South Africa is quite low: this might be because of under reporting, but the surveyors indicated that respondents forcefully argued that household members that had migrated keep the income they earn to themselves. The finding is also in line with Posel and Casale (2006) who found that the proportion of households receiving remittances declined since 1999 due to less secure forms of income, declining average real wages, and a reduced "perceived" need to pay remittances due to an increase in the value and coverage of social grants payments. In India, 40\% of the households report receiving remittances, a substantially higher percentage than the rest. Especially in Vietnam, household members are often engaged in different livelihood strategies, resulting in a relatively high share of households with multiple livelihood strategies. This reduces livelihood vulnerability, since failure of one strategy can be compensated with the returns from another income or subsistence source.

Table 1. Summary statistics on household composition and livelihood strategies.

\begin{tabular}{|c|c|c|c|c|}
\hline & $\begin{array}{l}\text { Mutale basin, } \\
\text { South Africa }\end{array}$ & $\begin{array}{l}\text { Terraba basin, } \\
\text { Costa Rica }\end{array}$ & $\begin{array}{l}\mathrm{Ba} \quad \mathrm{Be}-\mathrm{Na} \\
\text { hang, Vietnam }\end{array}$ & $\begin{array}{l}\text { Warana } \\
\text { basin, India }\end{array}$ \\
\hline Number of observations & 96 & 123 & 292 & 159 \\
\hline Number of villages & 4 & 4 & 10 & 4 \\
\hline Average household size & $4.8(2.1)$ & $3.9(1.7)$ & $4.8(1.6)$ & $5.3(2.4)$ \\
\hline Average no. of women per household & $2.5(1.3)$ & $2(1.1)$ & $2.4(1.3)$ & $2.7(1.5)$ \\
\hline Average no. of school going children/household & $1.7(1.4)$ & $1.1(1.2)$ & $1.2(1.1)$ & $1.2(1.1)$ \\
\hline Average no. of retired people per household & $0.25(0.5)$ & $0.2(0.5)$ & $0.06(0.2)$ & $0.03(0.16)$ \\
\hline \multirow{5}{*}{$\begin{array}{l}\text { \% of households (self-) employed in: } \\
\text { agriculture } \\
\text { industry/commerce } \\
\text { tourism } \\
\text { fish/forestry } \\
\text { public sector }\end{array}$} & $8 \%$ & $24 \%$ & $96 \%$ & $75 \%$ \\
\hline & $22 \%$ & $33 \%$ & $20 \%$ & $28 \%$ \\
\hline & $7 \%$ & $17 \%$ & $15 \%$ & $12 \%$ \\
\hline & $7 \%$ & $4 \%$ & $8 \%$ & 0 \\
\hline & $4 \%$ & $21 \%$ & $24 \%$ & $8 \%$ \\
\hline$\%$ of households with multiple strategies & $32 \%$ & $47 \%$ & $53 \%$ & $34 \%$ \\
\hline$\%$ of households receiving remittances & $8 \%$ & $14 \%$ & $5 \%$ & $40 \%$ \\
\hline
\end{tabular}

Illiterate households form less than $5 \%$ of the population in all study sites. 
Considering the monetary income that households derive from their livelihood strategies, Table 2 indicates that monetary incomes are on average low: compared to local poverty levels ${ }^{3}$ between $25-60 \%$ of the households in the study sites is income poor. Given that income only includes monetary income, this is likely to be an overestimate of the actual number of households that are poor. A better indicator might be the number of households that indicates sometimes having insufficient to eat. Table 2 indicates that in India and Costa Rica, 85-90\% of the households reported always having sufficient to eat, whereas in respectively Vietnam and South Africa 40 and $70 \%$ of the households did not have sufficient to eat during parts of the year.

Table 2. Summary statistics on income poverty, food security and coping strategies

\begin{tabular}{|c|c|c|c|c|}
\hline & $\begin{array}{l}\text { Mutale basin, } \\
\text { South Africa }\end{array}$ & $\begin{array}{l}\text { Terraba basin, } \\
\text { Costa Rica }\end{array}$ & $\begin{array}{l}\mathrm{Ba} \text { be-Na } \\
\text { hang, Vietnam }\end{array}$ & $\begin{array}{l}\text { Warana } \\
\text { basin, India }\end{array}$ \\
\hline Monetary income per capita (USD/month) & $91(96)$ & $214(253)$ & $13(14)$ & $9.9(7.7)$ \\
\hline$\%$ below the local poverty line & $49 \%$ & $25 \%$ & $62 \%$ & $50 \%$ \\
\hline$\%$ households with agriculture-based livelihood & $8 \%$ & $24 \%$ & $96 \%$ & $75 \%$ \\
\hline$\%$ households with sufficient to eat & $30 \%$ & $90 \%$ & $60 \%$ & $85 \%$ \\
\hline \multicolumn{5}{|l|}{$\begin{array}{l}\text { Coping strategies in times of stress ( } \% \text { of } \\
\text { households): }\end{array}$} \\
\hline Sells assets, works more & $31 \%$ & $51 \%$ & $56 \%$ & $6 \%$ \\
\hline Depends on government & $27 \%$ & $4 \%$ & $6 \%$ & $26 \%$ \\
\hline Depends on family/village & $29 \%$ & $27 \%$ & $34 \%$ & $32 \%$ \\
\hline
\end{tabular}

The high number of households not having sufficient to eat in South Africa may be explained by the fact that many households in the Mutale basin receive government food aid which is unsteadily supplied over time. In Vietnam, small property size and low productivity seem to explain the low level of food security. In India, the level of food security is surprisingly high, but the \% of households reporting that in times of hardship they have nothing to fall back on (ie become poorer) is double that in the other sites. Interestingly the \% of households that indicates that they can depend on social networks in times of hardship is in all sites approx. the same. Differences in coping strategies can be found mostly in the role of the government and the extent to which households can cope with emergencies by selling assets and working more.

Table 3 confirms that livelihood strategies in South Africa and Costa Rica are less agriculture-based: half of the households owns very little (South Africa) or no land (Costa Rica). Average landholding in Costa Rica is large but this is because few households own large amounts of (pasture) land. In South Africa, average landholding is substantial, but the quality of the land is generally very low. Also, none of the households has access to irrigation, whereas rainfall is confined to 3-4 months a year

\footnotetext{
${ }^{3}$ For each country we used the lower bound of the regional poverty level to assess whether the household should be classified as being poor.
} 
Table 3 Summary statistics on land- livestock ownership, drinking water and main source of fuel.

\begin{tabular}{|l|l|l|l|l|}
\hline & $\begin{array}{l}\text { Mutale basin, } \\
\text { South Africa }\end{array}$ & $\begin{array}{l}\text { Terraba basin, } \\
\text { Costa Rica }\end{array}$ & $\begin{array}{l}\text { Ba be -Na } \\
\text { hang, Vietnam }\end{array}$ & $\begin{array}{l}\text { Warana } \\
\text { basin, India }\end{array}$ \\
\hline \% of households with access to land & $58 \%$ & $24 \%$ & $98 \%$ & $92 \%$ \\
\hline Average landholding (acres) & $2.4(4.7)$ & $14.4(74.2)$ & $1.3(1.4)$ & $3.4(6)$ \\
\hline Access to irrigation (of the landowners) & 0 & 0 & $71 \%$ & $25 \%$ \\
\hline \% of households with livestock (excl chicken) & $59 \%$ & $9 \%$ & $91 \%$ & $65 \%$ \\
\hline Average no. of chicken per household & $4.8(5.7)$ & $4.5(11.2)$ & $12.9(21.4)$ & $2.7(7.6)$ \\
\hline$\%$ of households with individual/collective tap & $40 \%$ & $99 \%$ & $80 \%$ & $77 \%$ \\
\hline$\%$ of households with access to electricity & $82 \%$ & $100 \%$ & $94 \%$ & $78 \%$ \\
\hline$\%$ of households that use wood/charcoal fuel & $100 \%$ & $15 \%$ & $98 \%$ & $84 \%$ \\
\hline
\end{tabular}

In Vietnam and India most households are land owning, and land use is distributed quite equally, although average landholding is much larger in India than in Vietnam. This reflects the fact that most of the households in the Vietnamese sample are located inside the park or its bufferzone. Here, land use is strongly restricted and households are not allowed to increase their landholding size. Given that most households still use traditional production technologies, productivity is low and households are not food secure. Slash and burn practices are a problem, especially in $\mathrm{Na}$ Hang reserve, where some households still use this illegal practice to increase the size of their land. Many households have access to irrigation, usually by individually tapping water from natural streams. In India, landholdings near and inside the park are relatively large compared to more downstream farmers, but productivity is low. The main reason for the low productivity is lack of access to irrigation and use of traditional production technologies, most households growing subsistence crops.

Text box 2: Displacement and its impact on the livelihoods of Dhangar community in Warana basin, India

The Dhangar (shepherd) community mostly lives in the upper reaches of the Warana basin, near Chandoli park. There are about 19 dhangar wadas (hamlets) in Shahuwadi Taluka, one of the Talukas in the basin, and 13 of them are very remote. Unlike the shepherds in other areas (especially with smaller ruminants like goats and sheep) these shepherds are more of cattle rearers and presently do not migrate according to seasons. They are mostly settled. They also practice some form of shifting cultivation (though this practice is decreasing) and used to be engaged in free grazing in and around the forests. Apart from selling milk, they also process the milk into other products like ghee and cheese and sell them to eke out a living. Many of them are also involved in low external input based, subsistence agriculture. They have been affected most by the setting up of the Chandoli National Park. Many of these communities have been displaced (because of the Chandoli dam and the National Park) and have been re-located in plainer areas which are very different from their socio-cultural-environmental settings that are not conducive for their cattle rearing and their livelihood and cultural activities and practices. They have sold off most of their cattle because of the restrictions they face because of the National Park. In fact their livelihood strategy has gone through a radical change - earlier it was cattle rearing supplemented by subsistence agriculture and now it is the other way around and many of them are also involved in wage labour. 
With regard to livestock holdings, another important household asset, in Vietnam most households own livestock: cattle for ploughing and pigs and chicken for household consumption. In India, livestock holdings are mostly related to agricultural production (bullocks) or reflect that the household is part of the traditional sheep or cattle rearers caste (also see text box). Clearly, livestock holdings might have been affected by park establishment, like the ownership of other household assets such as land. In South Africa, households hold free-grazing cattle and goats for meat and donkeys for transportation. In Costa Rica few households own livestock, which reflects the urban lifestyle most households have.

Differences between sites in terms of non-productive ecosystem services uses are large: In South Africa almost $50 \%$ of the households depend on surface water for domestic water use and most households use wood as main source of fuel. In Costa Rica, people receive drinking water through water supply companies and use gas or electricity for cooking. In Vietnam and India the dependence on surface water for drinking is much lower, but the dependence on wood/charcoal is large (Vietnam) or medium (India), where people use cow dung instead of charcoal. Apart from the use of land and water for agricultural production and household consumption, households directly collect food, fuel, fodder and other resources from the ecosystem to support their livelihood. Table 4 presents the percentage of households using the ecosystem for the collection of specific goods.

Table 4 Summary statistics on the $\%$ of households collecting products from nature

\begin{tabular}{|c|c|c|c|c|}
\hline & $\begin{array}{l}\text { Mutale basin, } \\
\text { South Africa }\end{array}$ & $\begin{array}{l}\text { Terraba basin, } \\
\text { Costa Rica }\end{array}$ & $\begin{array}{l}\mathrm{Ba} \quad \mathrm{Be}-\mathrm{Na} \\
\text { hang, Vietnam }\end{array}$ & $\begin{array}{l}\text { Warana } \\
\text { basin, India }\end{array}$ \\
\hline Household does NOT collect any products & $2 \%$ & $29 \%$ & $3 \%$ & $13 \%$ \\
\hline \multirow{8}{*}{$\begin{array}{l}\text { Households collecting: } \\
\text { Meat } \\
\text { Fish } \\
\text { Fruits } \\
\text { Vegetables, mushrooms } \\
\text { Medicinal plants } \\
\text { Timber, construction material } \\
\text { Fuel } \\
\text { Flowers }\end{array}$} & $9 \%$ & $4 \%$ & $0 \%$ & $1 \%$ \\
\hline & $36 \%$ & $10 \%$ & $10 \%$ & $3 \%$ \\
\hline & $62 \%$ & $64 \%$ & $8 \%$ & $25 \%$ \\
\hline & $34 \%$ & $24 \%$ & $31 \%$ & $6 \%$ \\
\hline & $26 \%$ & $22 \%$ & $3 \%$ & $2 \%$ \\
\hline & $43 \%$ & $7 \%$ & $41 \%$ & $33 \%$ \\
\hline & $88 \%$ & $2 \%$ & $91 \%$ & $82 \%$ \\
\hline & $1 \%$ & $3 \%$ & $1 \%$ & $13 \%$ \\
\hline Average no. of products collected & $3.7(1.3)$ & $1.41(1.30)$ & $1.94(1.14)$ & $1.7(1.2)$ \\
\hline$\%$ of households collecting from protected area & $17 \%$ & $17 \%$ & $74 \%$ & $22 \%(47 \%)$ \\
\hline
\end{tabular}

It is important to note that, except for Vietnam, most of these products are not collected in a protected area. For India, the figure is likely to be biased since in the one village located inside the protected area all households indicated that they did not collect any products in the park (whereas in anonymous interviews they indicated that they did). Thus, between brackets a corrected figure, including all households inside the park. 


\section{Text box 3: Products sourced from nature in the Mutale River Basin, South Africa}

Trees, plants and wild fruits make for an important ecosystem service in the Mutale basin, South Africa. Food products that are mainly sourced from nature include wild grapes, ground nuts ("dovhi ") and "mbuyu" (Tshihwanambi 2007). Mbuyu is the fruit of the Baobab tree. The VhaVenda people make a porridge where the acidic flesh of this fruit is crushed and when mixed with milk it causes the milk to thicken and mildly ferment, giving this traditional dish its distinct taste. Mopani worms or what they call "mashonzha", although not necessarily recognised by the younger generations as such, forms an integral part of the protein intake of these people two seasons of the year. These worms can be eaten dried, deep fried or cooked in stews. Other sources of protein directly sourced from nature come from hunting wild rabbits and hyraxes more commonly known as "dassies". Wild leaves from the veld are cooked like spinach and is collectively known as "morogo" or "imifino"(Faber et al 2010). Dovhi groundnuts are then used to thicken sources or add flavour to wild spinach dishes such as "tshidzimba", "tshimbundwa" and" tshigume". Various plants and shrubs are sometimes used for medicinal purposes. "Delele" (herb better known as "Wild Jute") and "mushidzhi" (also known as "Black Jacks") are important for health reasons (Tshihwanambi 2007). "Matumba" or wood is a particularly important product sourced from nature. Wood is used for cooking, serves as fuel to provide heat and also for construction of houses, building storage space for maize (their staple food) as well as the "kraal", where livestock are kept. It is said that the VhaVenda, although some $82 \%$ of the respondents interviewed have electricity, prefer to make their porridge on the open fire since it tastes better (Makhado et al 2009). When asked about collection of firewood, the quantities they consume on a daily basis and conservation of nature, one of the respondents said: "The plants and trees will always be there for our use, because we are not cutting the living trees, only the dead ones".

In Costa Rica around a third of the households do not collect any products at all: these are mostly urban households who visit nature only occasionally for recreation. In all sites, households report that they mostly collect fruits, vegetables, fuel and construction materials, but in South Africa and Costa Rica a significant part of the households collects medicinal plants and dyes as well. In Costa Rica, these are indigenous households located inside the Boruca indigenous territory (see also text box). Hunting is not so often reported, but this might be because hunting is usually not allowed.

Turning to the importance of natural product collection for local livelihoods, table 5 presents the results of a Probit analysis aimed at determining the factors that explain whether the respondent considers the collection of natural products important for the household's livelihood or not. Shaded boxes represent significant factors (significant up to the $10 \%$ level). Given that the results presented are part of a Probit analysis, the size of the determinants cannot be easily interpreted. Hence, the main message of table 5 lies in the significance and sign of the variables explaining the stated importance of natural product collection for the household's livelihood. 
Table 5. Probit model explaining household stated importance of natural product collection

\begin{tabular}{|c|c|c|c|c|}
\hline & $\begin{array}{l}\text { Mutale basin, } \\
\text { South Africa }\end{array}$ & $\begin{array}{l}\text { Terraba basin, } \\
\text { Costa Rica }\end{array}$ & $\begin{array}{l}\text { Ba Be-Na hang, } \\
\text { Vietnam }\end{array}$ & $\begin{array}{l}\text { Warana basin, } \\
\text { India }\end{array}$ \\
\hline Constant & $-4.0(1.95)$ & $-2.09(.77)$ & $-.60(.84)$ & $-1.89(.80)$ \\
\hline $\begin{array}{l}\text { Household per capita income } \\
\text { (USD/month) }\end{array}$ & $.01(.005)$ & $-.000(.000)$ & $.01(.01)$ & $.06(.04)$ \\
\hline Household below poverty line & $-1.18(.66)$ & $.79(.39)$ & $.07(.28)$ & $1.03(.47)$ \\
\hline No. of hh members & $1.72(.58)$ & $-.06(.13)$ & $-.06(.06)$ & $-.08(.08)$ \\
\hline No of hh members below 18 & $-1.42(.51)$ & $.06(.16)$ & $.09(.10)$ & $.007(.13)$ \\
\hline Female respondent & $-.54(.66)$ & $-.03(.32)$ & $.11(.19)$ & $1.03(.38)$ \\
\hline Livestock owning household & $.52(.44)$ & $.03(.6)$ & $.77(.32)$ & $.02(.38)$ \\
\hline No. of natural products collected & $.57(.20)$ & $.69(.14)$ & $.51(.12)$ & $-.02(.16)$ \\
\hline $\mathrm{HH}$ has sufficient to eat & $1.33(.59)$ & $-.48(.44)$ & $-.41(.20)$ & $.34(.40)$ \\
\hline Wood/charcoal main source of fuel & Dropped & $.9(.36)$ & $.43(.52)$ & $1.90(.48)$ \\
\hline $\begin{array}{l}\text { Household belongs to countries } \\
\text { majority ethnic group }\end{array}$ & $-.47(.69)$ & $1.36(.47)$ & $-.17(.26)$ & $.59(.35)$ \\
\hline $\begin{array}{l}\text { Household belongs to countries } \\
\text { majority religious group }\end{array}$ & $.68(.63)$ & $.15(.31)$ & $-.47(.46)$ & Dropped \\
\hline No of observations & 92 & 118 & 266 & 130 \\
\hline Wald chi2 (11) & 13.12 & 52.21 & 44.22 & 28.26 \\
\hline Pseudo R2 & 0.369 & 0.337 & 0.164 & 0.331 \\
\hline
\end{tabular}

Robust standard errors between brackets

Interestingly, in Costa Rica, Vietnam and India it are the poor households that consider the collection of natural products important, whereas in South Africa it are the households that are better off. However, this last result is a bit distorted since including the size of household landholding shows that landholding perfectly predicts the importance of natural product collection ${ }^{4}$. Also in India, landholding size significantly predicts ecosystem dependence, showing that poor, landless households are more dependent on the ecosystem than households that have their own land. This is in line with the literature (Deland 2006, Bawa et al.2007) that indicates that poor households, i.e. with few assets, depend on the ecosystem for their livelihood more. In South Africa, the result is a bit different because the main part of household income comes from wage labor, state pensions and government grants. Here, the ecosystem seems to fulfil a safety net function for the very poor and a means of generating income for the relatively better off. The significant, positive sign of the number of household members below 18 supports this explanation, a higher number of child grants reducing the need for a safety net. Puzzlingly, households belonging to the majority ethnic group of a region are more likely to consider the collection of natural products important in Costa Rica and India than other households, whereas one would expect the importance of natural product collection to be especially high for minority ethnic groups.

\footnotetext{
${ }^{4}$ Since the model drops all observations that perfectly predict the dependant variable, the model specification presented in Table 5 does not include landholding size.
} 


\section{Text box 4: The use of natural resources for subsistence in the Boruca Indigenous Community}

The Boruca Indigenous Territory is found in the province of Puntarenas, in the county of Buenos Aires, and forms part of the lower basin of the Grande de Térraba River catchment area. Few opportunities for employment are available in Boruca communities; the main economic activities in the area are in agriculture or livestock. However, in the past decades the local economy has begun to transform itself due to the introduction of tourism and the subsequent demand of products and services for foreign visitors.

Today, the elaboration of handicrafts is one of the principal productive activities in the Boruca community, employing the majority of the working population. Unfortunately, the proliferation of handicraft production has had a negative impact upon the community, creating an excessive supply that is difficult to place within the market. The "overproduction" of craft items also has a negative impact on the environment, contributing to the scarcity of natural resources used in their fabrication, such as dyes extracted from mangrove trees as well as from mollusks native to the littoral zone.

Sales are greatly influenced by the tourist season for the reserve and surrounding areas, with a "high" period of five months, from May to October. The production of Boruca textiles is an economic activity maintained by many artisans who use pigments extracted from plants and trees in order to create their own home-made dyes. Currently, the designation of protected areas has limited access and possibilities for legal extraction of natural materials used to made traditional dyes like the trunks of mangrove trees and mollusk shells harvested from coastal areas and cliffs. In addition, the scarcity of shellfish and sea snails from which many dyes are extracted, due to the increase in harvesting for textile production, as well as subsequent difficulties in access as populations of these animals retreat to harder-to reach areas along the coast.

The traditional cultural practice of extraction of natural pigments and dye-making took place in two areas: gardens or cultivated areas where plants and flowers were extracted within indigenous settlements, and the seashore, outside of settlement areas. During the summer months indigenous communities migrated intermittently to coastal areas, mainly near the beaches of the Marine National Park (Ballena). The Boruca carried some food items to be cooked and consumed during this time, but generally complemented their usual diet with land animals, fish and crabs caught or hunted nearby the camps. Men and women worked to extract pigments and dye cloth. A morning's labor could produce only about 3 boards of cotton colored with extract from sea snails and shellfish, due to the small amount of secretions yielded by each animal and the difficulty inherent in their extraction. Finally, it is important to mention that one of the strategies that has been adopted by the Boruca artisan community in order to provide greater access to traditional dyes has been to reduce their use by not completely dyeing the fibers used, producing textiles with less-intense and non-uniform coloration. 
Summarizing, we find that livelihood-nature linkages differ between the study sites: In Vietnam and India linkages are strongest, whereas in Costa Rica and South Africa they are relatively weak. In Costa Rica this is because most people living in the Terraba basin have urban lifestyles, and only the indigenous communities living inside the Boruca indigenous territory and the fisher communities living inside the Terraba-Sierpe wetland still depend on nature directly for their livelihood. In the Mutale basin in South Africa, dependence on the ecosystem for non-productive uses is high, but for income people migrate to the city or depend on government pensions and child grants. Given that people have few assets and are generally very poor, the safety net function of the ecosystem does seem important in the South African context but the actual dependence of local livelihoods on nature is low. In the Vietnamese and Indian study sites, livelihoods are mostly agriculture-based and most households own a plot of land on which they cultivate (subsistence) crops. Livestock is important for agricultural production and consumption, and most households depend on the ecosystem for fodder and grazing land. In addition, people use the ecosystem to collect fruit, vegetables and construction materials and fuel. The collection of firewood is actually the most widespread livelihood-nature linkage in all study sites, except Costa Rica, with $80-100 \%$ of the households depending on firewood for fuel.

With regard to the relationship between poverty and nature, poor people depend more on the collection of natural products from nature in all study sites. In Vietnam, it are specifically the food insecure households that regard the collection of natural products important, in India and South Africa it are the landless households and in Costa Rica and India it are the income poor.

The differences between the sites in terms of the poverty-livelihood- nature linkages are important to acknowledge, since they imply that generic approaches to reduce poverty and improve biodiversity protection are unlikely to work. In South Africa, improving the quality of the ecosystem might carry important benefits in terms of improved water quality (health) and increased livestock production (food security), but is unlikely to have direct income generation effects. In Vietnam and India, biodiversity protection seems to generate important trade-offs: In Vietnam, scarcity of agricultural land is constraining local livelihoods, and in India people have actually been displaced. In Costa Rica, higher welfare levels and more urban lifestyles have mostly disconnected the protection of biodiversity and local livelihoods. Only for indigenous communities and fisher communities are the two still connected, but in both cases protected area management does not seem to constrain local livelihoods much.

In the next section we further elaborate how protected area management and local livelihoods are entwined. We discuss the implications of differing poverty-livelihoodnature linkages for biodiversity protection in the discussion of results. 


\section{Protected area establishment and community co-management}

In the survey we asked households whether they had been affected by the establishment of the nearby protected area (PA). Almost half of the households in India, Vietnam and South Africa indicated that they had been affected in one or the other way. In Costa Rica only $7 \%$ of the households reported having been affected, possibly because of the urban lifestyle of most of the households and because biodiversity protection is not externally enforced. In India, most of the affected households perceived the impact to be negative, whereas most of the households in Vietnam and South Africa were neutral or believed the park had had a positive effect.

Table 6 Summary statistics of the impacts of protected area establishment

\begin{tabular}{|l|l|l|l|l|}
\hline & $\begin{array}{l}\text { Mutale basin, } \\
\text { South Africa }\end{array}$ & $\begin{array}{l}\text { Terraba basin, } \\
\text { Costa Rica }\end{array}$ & $\begin{array}{l}\text { Ba be-Na hang, } \\
\text { Vietnam }\end{array}$ & $\begin{array}{l}\text { Warana basin, } \\
\text { India }\end{array}$ \\
\hline $\begin{array}{l}\% \text { households affected by } \\
\text { establishment of PA }\end{array}$ & $46 \%$ & $7 \%$ & $57 \%$ & $61 \%$ \\
\hline $\begin{array}{l}\% \text { households that consider impact } \\
\text { of PA to be negative }\end{array}$ & $11 \%$ & $2 \%$ & $10 \%$ & $52 \%$ \\
\hline $\begin{array}{l}\% \text { households that feel they can } \\
\text { influence PA management }\end{array}$ & $48 \%$ & $70 \%$ & $48 \%$ & $24 \%$ \\
\hline
\end{tabular}

The perceived impact of park establishment seems to at least partly reflect the extent to which local communities were involved in the establishment of the PA. In Chandoli national park, India, communities were not involved in park establishment and park establishment caused large conflicts because communities were displaced without compensation (Trepp 2010, also see text box). In Ba Be national park and $\mathrm{Na}$ Hang protected area in Vietnam, communities were involved in protected area establishment, and although their use of resources has been limited they are allowed to continue with their livelihood activities inside the boundaries of the park. In South Africa, communities were not consulted when the park was established during Apartheid, but are currently represented through tribal authorities in park management, although the extent to which they are well-represented is under debate (Medvey 2010). In Costa Rica, the TerrabaSierpe wetland protected area was formally established, but not implemented (Uribe 2010) and the Boruca indigenous territory is managed by communities themselves.

On the other hand, the perceived impacts reflect the extent to which households benefitted from the establishment of the PA: In South Africa and Vietnam, PA establishment has generated tourism revenues, and an increasing number of households receive some benefit through tourism from the park. In Costa Rica, tourism is an important source of income. In India, there is hardly any tourism, and international visitors are not even allowed inside the park. In South Africa and India park establishment also had negative impacts through increased wildlife-livelihood conflicts, households reporting that crop and livestock losses had increased. 
Text box 5: The dam, park and conflicts in the Warana basin, India

The Warana dam and the Chandoli National Park have caused a multi-layered conflict in the area especially on the issue of displacement and re-settlement. The Warana dam came up in 1985 and the catchment of the dam was first declared as a wildlife sanctuary in 1985 and then elevated to the status of a national park in 2004 with an area of $317.67 \mathrm{sq} \mathrm{km}$. In May 2007 it has been made part of Sahyadri Tiger reserve. In fact prior to the actual setting up of the national park the process of resettlement began in 1995-97. Twenty nine villages have been relocated to areas outside the park mostly to zone 2 and 3 in the basin and four villages are still remaining inside the park as they have been resisting eviction. Process to move them out of the park is still ongoing. The construction of the dam and later the establishment of the park have caused violent disruption of the livelihoods and socio-cultural practices of the people because of displacement and also the restrictions (ban) to collect any biomass, including wood and other forest resources from the park. Civil society organisations in the area have tried to organize the people affected by the dam and the park and they have been agitating against the government for proper rehabilitation. During the last two decades there have been many intense struggles and protests to get the demands of the displaced people accepted by the government. There have been also conflicts between the ousted people and the host communities as the oustees are rehabilitated by taking over land from larger land holders by applying land ceiling rules. There have been also conflicts within the affected villages on issues like whether to move out or not, where to move out and so on. The village Ghotne is an example of this. Though initially all the villagers were very united in resisting eviction, gradually fissured appeared amongst them - first one group decided to move out and then within the people who are still remaining there is conflict over where to move (as now they have realised that there is no other go but to move out).

To further analyze the extent to which households feel they can influence PA management, Table 7 presents the result of a probit analysis assessing the factors determining the probability that a household feels able to influence PA management. Interestingly in all study sites the perceived ability to influence village decision-making is an important explanatory factor, suggesting that influence in PA management is only partly determined by the organization of PA management itself. Household income has no significant influence, although a separate regression regarding the factors explaining the households perceived influence in village decision-making indicates that poor households feel less capable of influencing village decision-making than households that are better-off. In Costa Rica and India, agricultural households feel more able to influence PA decision-making, whereas in Vietnam households active in tourism and the public sector are more influential. The significant negative sign for livestock owning households in India is an indication that the indigenous Dhangar feel less capable of influencing PA decision-making, and in Vietnam the significant positive sign for majority religion (in Vietnam this is atheism) indicates that the indigenous and protestant Hmong people might not feel represented in PA decision-making well. 
Table 7 Probit model explaining the households perceived influence in PA management

\begin{tabular}{|c|c|c|c|c|}
\hline & $\begin{array}{l}\text { Mutale basin, } \\
\text { South Africa }\end{array}$ & $\begin{array}{l}\text { Terraba basin, } \\
\text { Costa Rica }\end{array}$ & $\begin{array}{l}\text { Ba be-Na hang, } \\
\text { Vietnam }\end{array}$ & $\begin{array}{l}\text { Warana basin, } \\
\text { India }\end{array}$ \\
\hline Constant & $-2.04(.83)$ & $-3.48(2.22)$ & $-1.62(1.01)$ & $-2.35(1.1)$ \\
\hline Distance to PA & $-.07(.04)$ & $1.03(.68)$ & $-.05(.05)$ & $-.11(.03)$ \\
\hline Location inside PA & Dropped & $3.49(2.16)$ & $-.09(.31)$ & $.20(.48)$ \\
\hline Agriculture & $.41(.56)$ & $.93(.40)$ & $-.44(.53)$ & $.89(.47)$ \\
\hline Industry & $-.27(.41)$ & $-.08(.39)$ & $.13(.24)$ & $.26(.31)$ \\
\hline Tourism & $-.28(.62)$ & $.07(.54)$ & $.60(.27)$ & $.68(.42)$ \\
\hline Public sector & $-.29(.66)$ & $.11(.39)$ & $.63(.27)$ & $.11(.48)$ \\
\hline $\begin{array}{l}\text { Household per capita income } \\
\text { (USD/month) }\end{array}$ & $.003(.003)$ & $.000(.000)$ & $.009(.01)$ & $.001(.03)$ \\
\hline Household below poverty line & $.04(.48)$ & $-1.11(.62)$ & $.46(.28)$ & $-.24(.43)$ \\
\hline Female respondent & $.30(.41)$ & $-.29(.37)$ & $-.50(.20)$ & $.21(.28)$ \\
\hline Land owning household & $-.03(.32)$ & $.28(.39)$ & $.66(.66)$ & $-.11(.45)$ \\
\hline Livestock owning household & $.11(.33)$ & $-1.24(.62)$ & $.31(.38)$ & $-.87(.36)$ \\
\hline Household can influence DS & $.84(.39)$ & $.45(.36)$ & $.40(.22)$ & $.95(.30)$ \\
\hline Village can influence DS & $1.64(.46)$ & $1.49(.40)$ & $.48(.20)$ & $.05(.27)$ \\
\hline $\begin{array}{l}\text { Household participates in voluntary } \\
\text { organization (excl church) }\end{array}$ & $.13(.37)$ & $.08(.38)$ & $-.21(.24)$ & $.81(.29)$ \\
\hline $\begin{array}{l}\text { Household belongs to countries } \\
\text { majority ethnic group }\end{array}$ & $.65(.45)$ & $.17(.46)$ & $-.000(.24)$ & $.29(.30)$ \\
\hline $\begin{array}{l}\text { Household belongs to countries } \\
\text { majority religious group }\end{array}$ & $-.19(.41)$ & $.46(.36)$ & $.91(.50)$ & $.72(.63)$ \\
\hline Respondent trusts other people & $-.60(.46)$ & $.25(.43)$ & $-.76(.20)$ & $-.35(.27)$ \\
\hline Respondent trusts authorities & $-.56(.34)$ & $-.12(.30)$ & $.24(.24)$ & $.41(.30)$ \\
\hline No of observations & 86 & 108 & 229 & 146 \\
\hline Wald chi2 (17) & 27.19 & 30.63 & 68.20 & 46.73 \\
\hline Pseudo R2 & 0.212 & 0.251 & 0.221 & 0.268 \\
\hline
\end{tabular}

Robust standard errors between brackets

The inclusion of the trust variables in the analysis requires some additional explanation Trust is an important factor for explaining community cooperation (Bouma et al. 2008) and given our interest in the potential for community co-management of PA we asked respondents whether they trusted other people and the authorities, using questions from the world values survey. It should be noted that the question regarding trust in local authorities was asked differently in the Vietnamese context, where villagers were asked whether they felt supported by the local authorities or not. As the summary statistics in table 8 indicate, trust in others is relatively high in Vietnam and India. This is in line with the literature, which indicates that trust in Asian societies is relatively high (Carpenter et al. 2004). When explaining the households perceived ability to influence PA management, trust is only significant in Vietnam, but adding trust as an explanatory variable significantly increased the explanatory power of the model overall. Table 8 presents summary statistics for some of the other explanatory variables including household membership of voluntary organizations and perceptions of village influence. 
Table 8 Summary statistics of trust levels, voluntary organization and influence in decision-making

\begin{tabular}{|l|l|l|l|l|}
\hline & $\begin{array}{l}\text { Mutale basin, } \\
\text { South Africa }\end{array}$ & $\begin{array}{l}\text { Terraba basin, } \\
\text { Costa Rica }\end{array}$ & $\begin{array}{l}\text { Ba Be -Na } \\
\text { hang, Vietnam }\end{array}$ & $\begin{array}{l}\text { Warana basin, } \\
\text { India }\end{array}$ \\
\hline$\%$ of household traditionally from the village & $86 \%$ & $72 \%$ & $91 \%$ & $98 \%$ \\
\hline $\begin{array}{l}\% \text { of households that feel they can influence } \\
\text { local decision making }\end{array}$ & $77 \%$ & $56 \%$ & $64 \%$ & $64 \%$ \\
\hline $\begin{array}{l}\% \text { of households that feel their village can } \\
\text { influence decision making }\end{array}$ & $78 \%$ & $61 \%$ & $54 \%$ & $60 \%$ \\
\hline $\begin{array}{l}\% \text { of households active in voluntary groups } \\
\text { (excl church) }\end{array}$ & $82 \%(62 \%)$ & $95 \%(50 \%)$ & $80 \%(80 \%)$ & $51 \%(44 \%)$ \\
\hline$\%$ of households that trust others & $14 \%$ & $21 \%$ & $43 \%$ & $49 \%$ \\
\hline$\%$ of households that trust local authorities & $52 \%$ & $34 \%$ & $19 \%$ & $67 \%$ \\
\hline
\end{tabular}

\section{Text box 6: Grassroot democracy and community consultation in Vietnam}

In Viet Nam, the Government has recognized the importance of involving households in decisions which affect their lives and of making local government more transparent and accountable in the announcement of Decree 29 on Grassroot Democracy. This is an exciting initiative which has the potential for mainstreaming the participation of poor and disadvantaged people in decision-making processes and of improving governance in Viet Nam. Normally the ways of carrying out community consultation are through a) large meetings, b) direct contact and c) by soliciting written comments. Specific tasks are identified for commune officials. They include discussing the draft manual socio-economic plan with villagers and seeking their feedback; disseminating government policies to villagers; providing information to villagers on projects and programs being implemented at the local level; holding biannual meetings between electorate and elected members of the People's Council; holding meetings to review their work in the presence of villagers, listening to their criticism; and planning and implementing village infrastructure works. Thus, the village chief has a key role to play in the implementation of grassroot democracy.

Turning to the effectiveness of PA management, we asked respondents whether they believed the rules regarding the use of natural resources in the PA were well-enforced. As the results presented in Table 9 indicate, rule enforcement is perceived to be relatively strong in Vietnam, and relatively weak in India. The very low \% of households knowing of rule breakers in India seems to have to do with fear: In anonymous interviews people said that they knew many examples of rule breaking (Trepp 2010) but this is not reflected in the survey results. The potential willingness to report rule breakers is in all sites relatively high, which could be an indication that there is a potential for protected area co-management, with communities playing a larger role in enforcement and control. Danielsen et al. $(2005,2008)$ indicate that community involvement in monitoring and enforcement can have a great impact on PA effectiveness, local communities having more information about the (illegal) use of PA resources, both by their own community members as by outsiders coming to the PA. 
Table 9 Summary statistics of the household's perceived influence on PA management

\begin{tabular}{|l|l|l|l|l|}
\hline & $\begin{array}{l}\text { Mutale basin, } \\
\text { South Africa }\end{array}$ & $\begin{array}{l}\text { Terraba basin, } \\
\text { Costa Rica }\end{array}$ & $\begin{array}{l}\text { Ba Be -Na } \\
\text { hang, Vietnam }\end{array}$ & $\begin{array}{l}\text { Warana basin, } \\
\text { India }\end{array}$ \\
\hline$\%$ households saying rules are well-enforced & $64 \%$ & $61 \%$ & $78 \%$ & $49 \%$ \\
\hline$\%$ of households knowing of rule breaking & $21 \%$ & $38 \%$ & $57 \%$ & $3 \%$ \\
\hline$\%$ of households willing to report & $66 \%$ & $86 \%$ & $66 \%$ & $58 \%$ \\
\hline
\end{tabular}

Turning to the factors that determine the willingness to report rule-breakers, the results in Table 10 suggest that in all study sites the household's perceived influence in PA management is a significant, positive determinant of the willingness to report. This finding holds across different model specifications.

Table 10 Probit model explaining the household's willingness to report rule-breakers

\begin{tabular}{|c|c|c|c|c|}
\hline & $\begin{array}{l}\text { Mutale basin, } \\
\text { South Africa }\end{array}$ & $\begin{array}{l}\text { Terraba basin, } \\
\text { Costa Rica }\end{array}$ & $\begin{array}{l}\text { Ba be-Na hang, } \\
\text { Vietnam }\end{array}$ & $\begin{array}{l}\text { Warana basin, } \\
\text { India }\end{array}$ \\
\hline Constant & $-1.6(1.3)$ & $-2.58(2.3)$ & $-1.14(.76)$ & $.28(.87)$ \\
\hline Distance to PA & $-.04(.05)$ & $.74(.62)$ & $.01(.05)$ & $-.08(.03)$ \\
\hline Location inside PA & Dropped & $1.46(2.69)$ & $-.02(.35)$ & $-1.08(.46)$ \\
\hline Agriculture & $-.16(.63)$ & $.35(.77)$ & $-.06(.58)$ & $-.59(.39)$ \\
\hline Industry & $.22(.53)$ & $.87(.64)$ & $.20(.26)$ & $.23(.27)$ \\
\hline Tourism & Dropped & $1.33(.76)$ & $-.04(.30)$ & $-.23(.37)$ \\
\hline Public sector & Dropped & $1.1(.92)$ & $.42(.27)$ & $-.23(.44)$ \\
\hline $\begin{array}{l}\text { Household per capita income } \\
\text { (USD/month) }\end{array}$ & $.01(.006)$ & $-.001(.000)$ & $.002(.012)$ & $.04(.03)$ \\
\hline Household below poverty line & $1.84(.83)$ & $-1.07(.97)$ & $.26(.32)$ & $-.09(.35)$ \\
\hline Female respondent & $.67(.58)$ & $1.03(.48)$ & $-.55(.21)$ & $-.02(.24)$ \\
\hline Land owning household & $-.86(.39)$ & $1.16(.56)$ & Dropped & $-.04(.45)$ \\
\hline Livestock owning household & $-.76(.43)$ & $-2.8(.90)$ & $.02(.38)$ & $.66(.35)$ \\
\hline Household can influence DS & $.02(.44)$ & $-.11(.47)$ & $.14(.23)$ & $-.30(.27)$ \\
\hline Village can influence DS & $.60(.58)$ & $.16(.43)$ & $-.05(.23)$ & $.17(.25)$ \\
\hline $\begin{array}{l}\text { Household participates in voluntary } \\
\text { organization (excl church) }\end{array}$ & $-1.18(.42)$ & $.13(.63)$ & $.17(.29)$ & $.09(.24)$ \\
\hline Household can influence PA & $1.60(.40)$ & $.81(.45)$ & $.81(.23)$ & $1.03(.37)$ \\
\hline $\begin{array}{l}\text { Household knows of people } \\
\text { breaking the rules }\end{array}$ & $.83(.53)$ & $-.99(.48)$ & $.33(.22)$ & $-.58(.71$ \\
\hline $\begin{array}{l}\text { Household belongs to countries } \\
\text { majority ethnic group }\end{array}$ & $-.23(.50)$ & $.21(.60)$ & $.73(.26)$ & $-.08(.29)$ \\
\hline $\begin{array}{l}\text { Household belongs to countries } \\
\text { majority religious group }\end{array}$ & $-.15(.55)$ & $2.56(.88)$ & $.56(.43)$ & $.17(.55)$ \\
\hline Respondent trusts other people & $2.88(1.12)$ & $-.65(.51)$ & $-.32(.23)$ & $.33(.24)$ \\
\hline Respondent trusts authorities & $.27(.38)$ & $.35(.55)$ & $-.16(.26)$ & $-.25(.25)$ \\
\hline No of observations & 75 & 108 & 224 & 145 \\
\hline Wald chi2 (17) & 26.53 & 27.52 & 64.83 & 27.30 \\
\hline Pseudo R2 & 0.325 & 0.428 & 0.248 & 0.178 \\
\hline
\end{tabular}

Robust standard errors between brackets 
Interestingly, and in line with the qualitative findings of anonymous interviews, households living inside Chandoli park in India are not willing to report rule breakers, probably because they do not trust park management and are not involved in PA management. Only in Vietnam does knowledge of rule breaking affect the willingness to report, which seems a bit awkward since one would expect to see such a relationship in the others sites as well. Household ethnicity and religion seem to play a role in Costa Rica and Vietnam. In Costa Rica the positive sign for majority religion (ie catholic) indicates that the protestant fishermen in the wetland might be less willing to report. Similarly, in Vietnam the positive sign for the majority ethnic group in the region, the Tay, indicates that minority groups might be less willing to report as well. The relationship between household income and poverty level and willingness to report is ambiguous: in India, better-off households are more willing to report, whereas in South Africa outcomes are mixed, in Costa Rica poorer households are more willing to report and in Vietnam income and poverty levels don't have a significant effect.

\section{Discussion}

This paper has analyzed poverty-livelihood-nature linkages in four biodiversity hotspots around the world and explored differences in the management of PA establishment and in the potential for community co-management. The analysis indicates that livelihoods in biodiversity hotspots do not necessarily depend on nature, but that nature does play an important safety net role. The differences in livelihood-nature linkages between the sites are substantial, which implies that generic approaches for addressing biodiversity protection and poverty alleviation jointly are unlikely to work. Giving local communities a role in PA management, however, would allow them to express their own needs and interests, and could improve the effectiveness of PA management at the same time. Cooperating in PA management requires however that households trust the authorities and have a direct benefit from a better management of the park (Danielsen et al. 2008). We did not find a significant impact of trust in the authorities on the willingness to report rule-breakers, which might be explained by the fact that we asked about trust in the authorities in general and not park management per se. However, our understanding of the different poverty-livelihood-nature linkages gives an indication that households in Vietnam and Costa Rica might be more willing to cooperate in PA management than in South Africa and India. In India, PA establishment has caused great conflicts and the perceived legitimacy of the park is low. In South Africa, PA management has been more inclusive, with tribal authorities representing households in the management of the PA, but people's livelihoods hardly benefit from improved PA management, benefits are mostly indirect through the safety net. In these countries, alternative livelihood investments might be more effective for alleviating poverty, without a link to the PA. 
In India, there might be scope for PA co-management in the future, but this would first require acknowledgement of the rights of local communities in the use of resources in the park. In Costa Rica, fishermen in the Terraba-Sierpe wetland would have an incentive to cooperate in PA management, which could improve the effectiveness of biodiversity protection in the wetland as well (Nirain 2010). In the Boruca indigenous territory, communities already cooperate in PA management, and the willingness to report is high. In Vietnam, communities could have a clear benefit from being involved in PA management, but the willingness to report is rather low. This might be because of the current top-down enforcement of the land use restrictions and the fact that communities living in the park are strongly constrained in their use of resources in the park. Investments in agricultural intensification, a sharing in the benefits of tourism generation and a larger role in rule setting could give local communities a large incentive to cooperate in a more sustainable use. Clearly, this requires further research into the conditions for community co-management and the incentives to contribute to the monitoring and enforcement of protected area land use restrictions and rules.

(To be further elaborated)

\section{Acknowledgements}

The authors would like to acknowledge the support of the European Commission through the FP7 program ENV.2007.2.1.4.3 Biodiversity values, sustainable use and livelihoods, LiveDiverse Project 211392. Also, they would like to acknowledge the efforts of the household survey teams and of Elisa Trepp, Paulina Gonzalez Pichardo, Aine Nirain, Jelena Perunicic and Lisette van Marwijk for their help with the data collection. 


\section{References}

Anand, S. and Sen, A. (1997). Concepts of human development and poverty: a multidimensional perspective, Human development papers, UNDP

Andam, K.S., Ferraro, P.J., Sims, K.R., Healy, A. and Holland, M. (2010). Protected areas reduced poverty in Costa Rica and Thailand. PNAS 107 (22): 9996-100001

Barrett, C., D.Lee and J.McPeak (2005). 'Institutional arrangements for rural poverty reduction and resource conservation', World Development 33(2): 193-197

Bawa, K., Joseph, G., Setty, S. (2007). Poverty, biodiversity and institutions in forest-agriculture ecotones in the Western Ghats and Eastern Himalaya ranges of India, Agriculture, ecosystems and environment 12:287-295

Bouma, J.A., E.H. Bulte and D.P. van Soest (2008). 'Trust and cooperation- Social capital and community resource management', Journal of Environmental Economics and Management 56: 155-166

Carpenter, J.P., A. Daniere, L. Takahashi (2004). Cooperation, trust and social capital in Southeast Asian urban slums, Journal of Economic Behavior and Organization 55: 533-551.

Cernea, M.M. and K. Schmidt-Soltau (2006). Poverty risks and national parks: Policy issues in conservation and resettlement. World development 34 (10): 1808-1830

Danielsen, F., Jensen, A., Alviola, P., Balete. D., Mendoza, M., TagTag, A., Costoio, C., Enghoff, M. (2005). Does monitoring matter? A quantitative assessment of management decisions from locally-based monitoring of protected areas, Biodiversity and Conservation 14: 2633-2652

Danielsen, F., Burgess, N., Balmford, A., Domald, P., Funder, M., Jones, J., Alviola, P., Balete, D., Blomley, T., Brashares, J., Child, B., Enghoff, M., Fjeldsla, J., Holt, S., Hubertz, H., Jensen, A., Jensen, P., Massao, J., Mendoza, M., Ngaga, Y., Poulsen, M., Rueda, R., Sam, M., Skielbo, T., Stuart-hill, G., Topp-jorgensen, E., Yonten, D. (2008). Local participation in natural resource monitoring: a characterization of approaches, Conservation biology 23 (1): 31-42

Dasgputa, S., Deichmann, U.,Meisner, C., Wheeler,D. (2004). Where is the Poverty-Environment Nexus? Evidence from Cambodia, Lao PDR, and Vietnam, World Development 33(4): 617-638

Deland, C. (2006). Not just minor forest products: The economic rationale for the consumption of wild food plants by subsistence farmers, Ecological Economics 59: 64-73

Faber, M, Oelofse, A., Van Jaarsveld, P.J., Wenhold, F.A.M., and Jansen van Rensburg, W.S. (2010) African Leafy vegetables consumed by households in the Limpopo and KwaZulu-Natal provinces in South Africa. S Afr J Clin Nutr 23(1):30-38

Fisher, B. and T. Cristopher (2007). 'Poverty and biodiversity: Measuring the overlap of human poverty and the biodiversity hotspots', Ecological Economics 62: 93-101

Hayes, T.M. (2006). Parks, People, and Forest Protection: An Institutional Assessment of the Effectiveness of Protected Areas. World Development 34 (12): 2064-2075

Hill, M., Hallam, D. and Bradley, J (1997) Site study; Ba Be NationalPark, Cao Bang Province, Vietnam. SEE-Vietnam Research Report 3. London: Society for Environmental Exploration.

Keane, A., Jones, P., Edwards-jones, G., Milner-Gulland, E. (2008). The sleeping policeman:understanding issues of enforcement and compliance in conservation, Animal conservation 11:75-82

Lahiff, E. (1997). Rural Resources Rural Livelihoods Working Paper Series. Paper No 7. Land, Water and Local Governance in South Africa: A Case Study of the Mutale River Valley. Pp. 118

Makhado, R.A., Potgieter, M.J., and Wessels, D.C.J. (2009). Colophospermum mopane Wood Utilisation in the Northeast of the Limpopo Province, South Africa. Ethnobotanical Leaflets 13: 921-45. 2009 
Medvey, J. (2010). Benefits or burden? Community participation in natural resource management in the Greater Kruger Park area. MsC thesis, Institute for Environmental Studies (IVM), VU University, the Netherlands, www.livediverse.eu

Millennium Ecosystem Assessment (2005). Ecosystems and Human Well-being: Biodiversity Synthesis. World Resources Institute, Washington, DC.

Nirain, A. (2010) Direct approaches to improving livelihoods and conserving biodiversity in the Rio Terraba Basin. MsC thesis, Institute for Environmental Studies (IVM), VU University, the Netherlands, www.livediverse.eu

Posel, D. and Casale, D. (2006). Migration and remittances in South Africa. Background document on migration and first set of draft questions for inclusion in the National Income Dynamics Study. University of KwaZulu-Natal, Department of Economics. Pp. 58.

Salafsky, N and E.Wollenberg (2000). 'Linking livelihoods and conservation: a conceptual framework and scale for assessing the integration of human needs and biodiversity', World development 28 (8): 14211438

Sen, A.( 1983). Poverty, relatively speaking, Oxford economic papers 35 (2): 153-169

Sen, A. (1995). Rationality and social choice, American Economic Review 85 (1):1-24

Sims, K. (2010). Conservation and development: evidence from Thai protected areas, Journal of Environmental Economics and Management 60: 94-114

Steffan-Dewenter et al. (2007). Tradeoffs between income, biodiversity, and ecosystem functioning during tropical rainforest conversion and agroforestry intensification. PNAS 104(12): 4973-78

Stern, M. (2008). Coercion, voluntary compliance and protest: the role of trust and legitimacy in combating local opposition to protected areas, Environmental Conservation 35 (3): 200-210

Sunderlin, W, A.Angelsen, B.Belcher, P.Burgess, R.Nasi, L.Santoso and S.Wunder (2005). 'Livelihoods, forests and conservation in developing countries: an overview', World Development 33 (9): 1383-1402

TEEB (2009) The Economics of Ecosystems and Biodiversity for National and International Policy Makers - Summary: Responding to the Value of Nature, http://www.teebweb.org/LinkClick.aspx?fileticket=dYhOxrQWffs\%3d\&tabid=1019\&mid=1931

Trepp, E (2010). Chandoli National Park and Resettlement: Impacts on Local Communities in Maharashtra, India, MsC thesis, Institute for Environmental Studies (IVM), VU University, the Netherlands, www.livediverse.eu

Tshihwanambi, T.P. (2007). Consumption patterns of Vaitamin-A rich foods of $10-13$ year old children living in a rural area in Venda. Masters Dissertation: Consumer Science. University of Pretoria

UN (2010). High-level meeting of the general assembly as a contribution to the international year of biodiversity, A/64/865, United Nations General Assembly, New York

Uribe, M (2010). Terraba Sierpe Wetland's Management plan: struggling for policy change and its implementation, MsC thesis, Institute for Environmental Studies (IVM), VU University, the Netherlands, www.livediverse.eu

Wittmyer, G., P. Elsen, W.T. Bean, A. Coleman, O. Burton, J.S. Brashares (2008). 'Accelerated human population growth at protected area edges', Science 321: 123-126 


\section{Annex: Overview of household survey variables used in analysis}

\begin{tabular}{|c|c|}
\hline Variable & Type of variable and interpretation \\
\hline Distance to PA & $\mathrm{Km}$ to the fence of the protected area (PA) \\
\hline Location inside PA & Dummy variable, $=1$ when village is located inside $\mathrm{PA}$ \\
\hline Agriculture & $\begin{array}{l}\text { Dummy variable, }=1 \text { when at least one member of household } \\
\text { is self-employed in agriculture }\end{array}$ \\
\hline Industry/commerce & $\begin{array}{l}\text { Dummy variable },=1 \text { when at least one member of household } \\
\text { is self-employed in commerce/industry }\end{array}$ \\
\hline Tourism & $\begin{array}{l}\text { Dummy variable },=1 \text { when at least one member of household } \\
\text { is self-employed in tourism }\end{array}$ \\
\hline Public sector & $\begin{array}{l}\text { Dummy variable },=1 \text { when at least one member of household } \\
\text { is employed in the public sector }\end{array}$ \\
\hline Household per capita income (USD/month) & 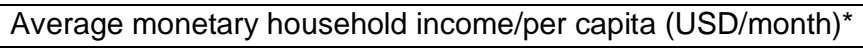 \\
\hline Household below poverty line & $\begin{array}{l}\text { Dummy variable, }=1 \text { when household per capita income is } \\
\text { below the underbound of the regional poverty line }\end{array}$ \\
\hline No. of $\mathrm{HH}$ members & Number of household members \\
\hline No of hh members below 18 & Number of household members with age below 18 \\
\hline Female respondent & Dummy variable, $=1$ when respondent is female \\
\hline Land owning household & Dummy variable, $=1$ when household owns land (user right) \\
\hline Size of landholding (acres) & Size of the landholding in acres \\
\hline Livestock owning household & Dummy variable, $=1$ when household owns livestock \\
\hline No. of natural products collected & No. of natural products collected in nature \\
\hline $\mathrm{HH}$ has sufficient to eat & $\begin{array}{l}\text { Dummy variable, }=1 \text { when household reports having always or } \\
\text { usually sufficient to eat }\end{array}$ \\
\hline Wood/charcoal is the main source of fuel & $\begin{array}{l}\text { Dummy variable, =1 when household reports using } \\
\text { firewood/charcoal as main source of fuel }\end{array}$ \\
\hline $\begin{array}{l}\text { Household can influence village level decision- } \\
\text { making }\end{array}$ & $\begin{array}{l}\text { Dummy variable, }=1 \text { when household always, often or } \\
\text { sometimes feels able to influence village decision-making }\end{array}$ \\
\hline Village can influence decision-making at higher levels & $\begin{array}{l}\text { Dummy variable, }=1 \text { when household always, often or } \\
\text { sometimes feels that the village can influence decision-making }\end{array}$ \\
\hline $\begin{array}{l}\text { Household participates in voluntary organization (excl } \\
\text { church) }\end{array}$ & $\begin{array}{l}\text { Dummy variable, }=1 \text { when households participates in a } \\
\text { voluntary organization (excluding church) }\end{array}$ \\
\hline Household belongs to countries majority ethnic group & $\begin{array}{l}\text { Dummy variable, }=1 \text { when household is part of the regions } \\
\text { majority ethnic group (Vhembe in South Africa, Costarican in } \\
\text { Costa Rica, Tay in Vietnam and Marathi in India) }\end{array}$ \\
\hline $\begin{array}{l}\text { Household belongs to countries majority religious } \\
\text { group }\end{array}$ & $\begin{array}{l}\text { Dummy variable, }=1 \text { when household is part of the regions } \\
\text { majority religious group (i.e. christian in South Africa, catholic } \\
\text { in Costa Rica, atheist in Vietnam and hindu in India) }\end{array}$ \\
\hline Respondent trusts other people & $\begin{array}{l}\text { Dummy variable, }=1 \text { when respondent states that people can } \\
\text { always or usually be trusted }\end{array}$ \\
\hline Respondent trusts authorities ${ }^{\star *}$ & $\begin{array}{l}\text { Dummy variable, }=1 \text { when respondent states that authorities } \\
\text { can be somewhat or completely be trusted }\end{array}$ \\
\hline Household can influence PA & $\begin{array}{l}\text { Dummy variable, }=1 \text { when households always, often or } \\
\text { sometimes feels able to influence PA management }\end{array}$ \\
\hline Household knows of people breaking the rules & $\begin{array}{l}\text { Dummy variable, }=1 \text { when household report knowing of many } \\
\text { or few local households and/or outsiders breaking the rules }\end{array}$ \\
\hline
\end{tabular}

* 1 USD $=7$ South African Rand= 500 Costarican colones= 20,000 Vietnamese Dong=50 Indian roepies

** In Vietnam, the question was phrased differently as 'Do you feel supported by the authorities in your livelihood?' 